\title{
Toxic elements as biomarkers for breast cancer: a meta-analysis study
}

This article was published in the following Dove Press journal: Cancer Management and Research

Leila Jouybari'

Marzieh Saei Ghare $\mathrm{Naz}^{2}$

Akram Sanagoo'

Faezeh Kiani ${ }^{3}$

Fatemeh Sayehmiri ${ }^{4}$

Kourosh Sayehmiri ${ }^{5}$

Ali Hasanpour Dehkordi ${ }^{6}$

'Nursing Research Center, Goletsan University of Medical Sciences,

Gorgan, Iran; ${ }^{2}$ Student Research Committee, School of Nursing and Midwifery, Shahid Beheshti University of Medical Sciences, Tehran, Iran; ${ }^{3}$ Student Research Committee, llam University of Medical Sciences, llam, Iran; ${ }^{4}$ Proteomics Research Center, Shahid Beheshti University of Medical Sciences, Tehran, Iran; ${ }^{5}$ Department of Social Medicine, School of Medicine, Ilam University of Medical Sciences, Ilam, Iran; ${ }^{6}$ Department of Medical Surgical, Nursing and Midwifery, Shahrekord University of Medical Sciences, Shahrekord, Iran
Correspondence: Akram Sanagoo Nursing Research Center, Golestan University of Medical Sciences, Hirkan Boulevard, Gorgan 49341745I5, Iran

Tel +98 I73245 I360

Email sanagoo@goums.ac.ir
Aims and background: Breast cancer (BC) is responsible for a large proportion of incidence of cancer in the world. Identifying the risk factors contributing to the incidence of $\mathrm{BC}$ is crucial to find efficient preventive and management strategies for this disease. Several studies have examined Arsenic (As), Cadmium (Cd), and Nickel (Ni) as risk factors for BC. The present study aimed at studying the link between $\mathrm{As}, \mathrm{Cd}$, and $\mathrm{Ni}$ concentrations and $\mathrm{BC}$ by using a meta-analysis.

Materials and methods: All case-control studies addressing the relationship between $\mathrm{As}, \mathrm{Cd}$, and Ni concentrations with $\mathrm{BC}$ were identified through electronic search databases (Scopus, ISI Web of Science, PubMed, EmBase, and Cochrane Library). The relevant data obtained from these papers were analyzed by a random-effects model. The heterogeneity of studies was secured by using $I^{2}$ index. Funnel plots and Egger's test were used to examine publication bias.

Results: In the present study, due to different measurement methods used for measuring As, Cd, and $\mathrm{Ni}$, the concentration of these elements was measured in various subgroups (1: plasma, 2: breast tissue, and 3: scalp hair and nail) of individuals with BC and healthy subjects. The overall integration of data from the 3 groups led to the conclusion that there was a significant difference in $\mathrm{Cd}$ and Ni statuses between healthy and BC patients; the standard mean difference was 2.65 (95\% CI: $1.57-3.73 ; P=0.000)$ and 2.06 (95\% CI: $1.20-3.32 ; P=0.000)$, respectively. Whereas, there was no significant statistical difference in As status between healthy subjects and BC patients; the standard mean difference between them being 0.52 (95\% CI: $-0.12-1.16 ; P=0.114$ ). Conclusion: The present study indicates that there is a direct and positive association between $\mathrm{Cd}$ and $\mathrm{Ni}$ concentrations and $\mathrm{BC}$ risk. It is a warning to health care providers and policy makers to find viable solutions and take requisite measures to reduce $\mathrm{BC}$ risk in the society.

Keywords: malignancy, breast cancer, arsenic, cadmium, nickel, meta-analysis, toxic element

\section{Background}

Among all cancers, breast cancer (BC) is the most common cancer in the world. ${ }^{1}$ Today, an increasing prevalence of cancer risk factors and population age has led to an increased rate of cancer, ${ }^{2,3}$ including $\mathrm{BC},{ }^{4,5}$ where one in nine women will develop breast cancer during their lifetime. $\mathrm{BC}$ is also the most common cause of cancer death among women and contributes to a substantial proportion of the global cancer burden. ${ }^{6-9}$

Various studies have shown that increasing age is the initial factor for many women developing BC. ${ }^{10}$ Another factor contributing to the increased risk of $\mathrm{BC}$ is the inheritance of a mutation in $B R C A 1$ or $B R C A 2$ genes. ${ }^{11}$ Moreover, lifestyle and environment are 2 of the most important factors for developing BC. ${ }^{12}$ Some studies have demonstrated that a number of variables, including genetic background and environmental factors, 
are involved in the development of BC. ${ }^{10-12}$ The major risk factors for developing $\mathrm{BC}$ include advancing age, family history, genetic factors, diet, lifestyle, obesity, smoking, alcohol consumption, early menarche, late menopause, older age at first birth, history of unilateral cancer, reproductive factors and hormones, some other malignancies such as ovary and endometrial carcinoma, and exposure to carcinogens (e.g., metal compounds). ${ }^{10-13}$

Various studies have established the relationship between exposure to metallic compounds and the risk of developing BC. ${ }^{14}$ Toxic metals are known risk factors for a variety of cancers. ${ }^{15-18}$

Each of the toxic elements, including Arsenic (As), Cadmium (Cd), and Nickel (Ni), is classified in human carcinogen group 1 by the World Health Organization (WHO). ${ }^{19}$ It was shown that As can induce chromosomal disorders and conversion of chromatids. ${ }^{20}$ These toxic elements can lead to cancer by alterations they induce in cell differentiation and proliferation, and an increase in cellular tyrosine phosphorylation, which is associated with abnormal cellular signaling and uncontrolled cell growth. ${ }^{21-23}$

Cd inhibits DNA synthesis, mismatch repair, and enzyme function. ${ }^{24} \mathrm{Ni}$ compounds with inhibition of intercellular connection could exhibit tumor-promoting ability through some mechanisms, such as ${ }^{25}$ immortalization of epithelial cells, ${ }^{26}$ generation of DNA protein cross-links, blockage of nucleotide cutting repair, ${ }^{27}$ and an increase in gene expression through DNA methylation. ${ }^{28}$

The high prevalence of mortality and morbidity in BC patients worldwide warrants comprehensive plans to prevent and cure this disease. Strategies and programs for the prevention of non-communicable diseases have all emphasized appropriate evaluation and management of risk factors. Preventing risk factors of $\mathrm{BC}$ may not only reduce the incidence of $\mathrm{BC}$ in the population but also enhance the efficacy and improve the prognosis of expensive therapies currently used for its treatment. As the toxic elements such as As, $\mathrm{Cd}$, and $\mathrm{Ni}$ have been found to be risk factors for BC in some studies, it is of paramount importance to investigate their influence on $\mathrm{BC}$, which can be an important approach for prevention and treatment of this disease. There are various reports with different findings on the critical role of toxic elements in the pathogenesis of $\mathrm{BC}$ and several studies have underscored the association between $\mathrm{As}, \mathrm{Cd}$, and $\mathrm{Ni}$ concentrations in individuals with BC. Thus, in order to confirm the findings of conducted studies hitherto, performing a meta-analysis is necessary. It seems that the assessment of the influence of heavy metals (As, Cd, and $\mathrm{Ni}$ ) in $\mathrm{BC}$ via meta-analysis can result in an overall and clear understanding of this disease; combination of different studies via meta-analysis can lead to an appropriate sample size and better resolution. It can also provide an overall precise and valid understanding of the problem as compared with other studies. The aim of this study was to provide an overall summary measure of the influence of $\mathrm{As}, \mathrm{Cd}$, and $\mathrm{Ni}$ on $\mathrm{BC}$ by reviewing available studies.

\section{Materials and methods}

\section{Search strategy}

An extensive search was carried out in English databases, including Scopus, PubMed /Medline, EmBase, Cochrane Library, and ISI Web of Science, for published case-control studies up to February 2015. The following keywords were used in the search: Breast Cancer, toxic elements, Arsenic (As), Cadmium (Cd), Nickel (Ni), plasma concentration, breast tissue concentration, Scalp Hair concentration, toenail concentration and their combination. To expand the search, the wildcard symbol "*” was used and the search words or phrases were combined using Boolean operators. Furthermore, reference lists of all the relevant original and review articles were manually searched for additional references. Our meta-analysis was limited to studies published in English.

\section{Inclusion and exclusion criteria}

All epidemiologic manuscripts containing the keywords in their titles or abstracts were collected. Eligible studies included epidemiologic manuscripts that analyzed As, Cd, and $\mathrm{Ni}$ levels in $\mathrm{BC}$ patients and healthy subjects. We limited the final review to studies conducted on humans. Studies in languages other than English were excluded, since they were not epidemiologic and case-control studies, presented insufficient data, or were not conducted on humans (i.e., animal studies). Review articles, meta-analyses, or duplicate publications were also excluded.

\section{Data extraction}

In this study, essential data such as first author, year of publication, location, sample size, $\mathrm{As}, \mathrm{Cd}$, and $\mathrm{Ni}$ concentrations in patients and healthy individuals, mean difference, As, Cd, and Ni screening method and sample specimens were extracted (Figure 1 for study flow chart). The articles were independently reviewed by 2 authors and discrepancies between them were resolved in a joint meeting through consensus. The data were entered into data collection forms and Microsoft Excel. This article was written according to PRISMA guidelines. ${ }^{68}$ 


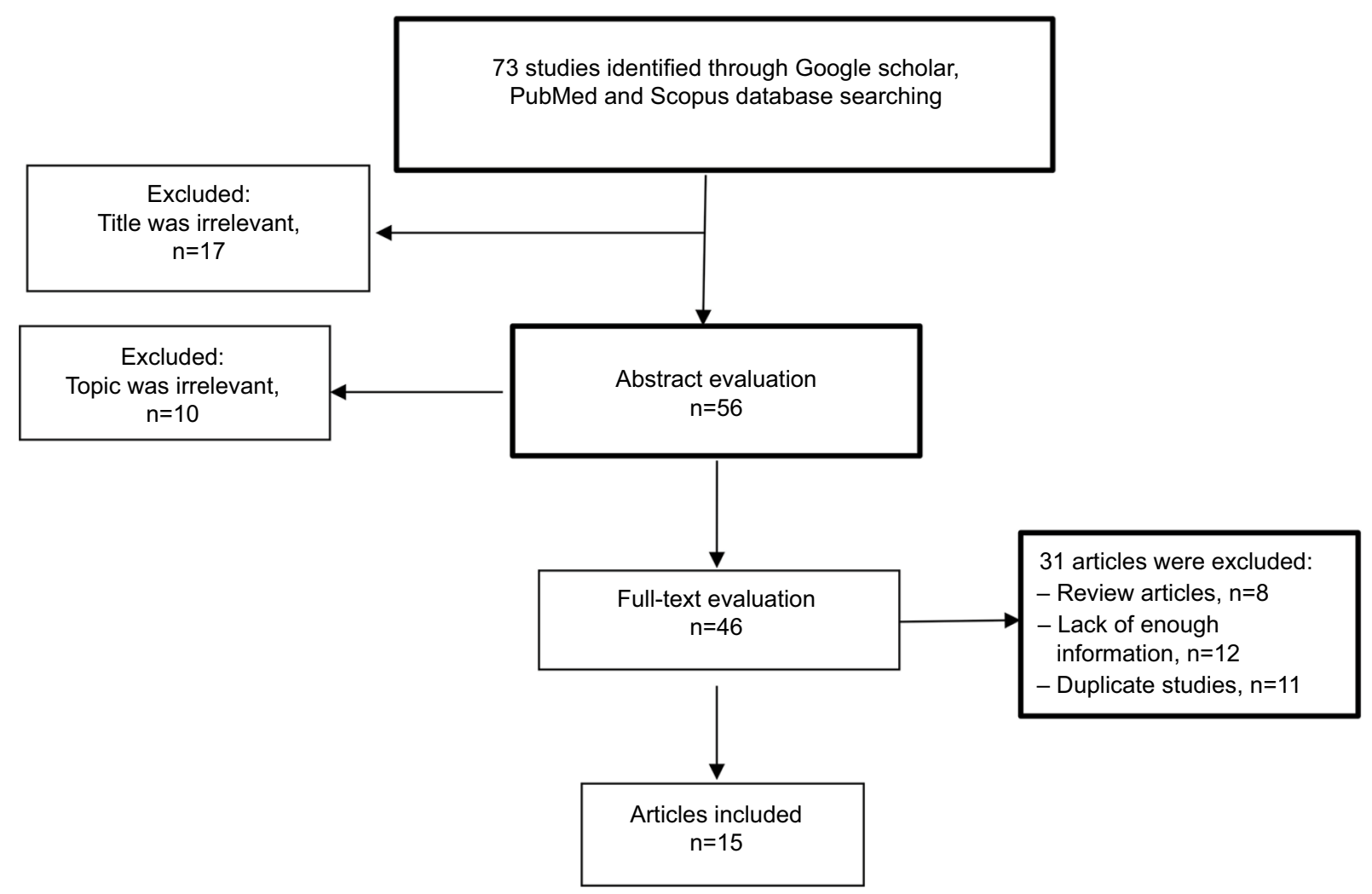

Figure I Flow diagram of studies identified in the systematic review and meta-analysis.

\section{Statistical analysis}

Studies were combined based on the sample size, mean, and SD. The difference between the average variance of the normal distribution of each study was calculated using the binomial distribution formula. To assess heterogeneity of the studies, $Q$-test and the $I^{2}$ index were used. Due to the importance of heterogeneity in the studies, random-effects model was used. In this meta-analysis, publication bias was checked using funnel plot and Begg's test. Sensitivity analysis was carried out to find the impact of the major studies on overall results. STATA software (version 14) was used to analyze the data. $P<0.05$ was considered as a significant level in the testing of the hypnosis.

\section{Results}

Our search strategy yielded 73 potential articles for inclusion. In the initial screening, based on title and abstract evaluation, 27 articles were excluded and 46 retained for further evaluation. In the next step, we excluded another 31 articles (8 review articles, 12 articles for lack of enough information, and 11 duplicate articles) based on full-text evaluation. Finally, 15 case-control studies that were published between 1984 and 2015 were selected to enter the meta-analysis ${ }^{19,24,35,36,52-56,69-73}$ (Figure 1). Taking into consider- ation all the included studies, the total sample size was 2274 individuals, of whom 1235 patients had BC and 1039 were healthy subjects. General characteristics of the 15 selected studies in this meta-analysis are summarized in Table 1. Effect size was defined as standard mean deference (SMD). The variance of SMD was calculated using normal distribution.

It was observed that the standard units for measuring $\mathrm{Cd}$, $\mathrm{Ni}$, and As concentrations differed in the selected studies. In some articles, microgram per liter $(\mu \mathrm{g} / \mathrm{L})$ was used and in others microgram per gram $(\mu \mathrm{g} / \mathrm{g})$ was reported, therefore we used SMD in analysis.

Also, the selected studies differed in terms of their type of sample specimens. Thus, in the present study, due to different measurements of $\mathrm{Cd}, \mathrm{Ni}$, and $\mathrm{As}$ concentrations, the levels of these elements in patients with $\mathrm{BC}$ and healthy subjects were measured in various subgroups (1: plasma, 2: breast tissue, and 3: scalp hair and toenail). Table 2 presents the overall results obtained from the analysis of the extraction data on the relationship between $\mathrm{As}, \mathrm{Cd}$, and $\mathrm{Ni}$ concentrations with $\mathrm{BC}$ in various subgroups.

We identified 11 studies reporting the association between Cd concentrations and $\mathrm{BC}$.

Among these studies, 7 showed a significant association between $\mathrm{Cd}$ concentrations and $\mathrm{BC}$ risk, whereas the other 4 
Table I Study characteristics

\begin{tabular}{|c|c|c|c|c|c|c|c|c|}
\hline \multirow[t]{2}{*}{ Reference } & \multirow{2}{*}{$\begin{array}{l}\text { Country } \\
\text { (year of } \\
\text { publication) }\end{array}$} & \multirow[t]{2}{*}{ Case } & \multirow[t]{2}{*}{ Control } & \multirow[t]{2}{*}{ Matrix } & \multicolumn{3}{|c|}{$\begin{array}{l}\text { Standard mean difference } \\
(95 \% \mathrm{Cl})\end{array}$} & \multirow[t]{2}{*}{$\begin{array}{l}\text { Type of } \\
\text { measurement }\end{array}$} \\
\hline & & & & & $\overline{C d}$ & $\mathbf{N i}$ & As & \\
\hline Antila et $a^{169}$ & Finland (1996) & 43 & 32 & $\begin{array}{l}\text { Breast } \\
\text { tissue }\end{array}$ & $\begin{array}{l}-0.39 \\
(-0.85 \text { to } 0.07)\end{array}$ & NR & NR & AAS \\
\hline lonescu et $\mathrm{al}^{70}$ & $\begin{array}{l}\text { Czech } \\
\text { Republic, } \\
\text { Germany } \\
(2006)\end{array}$ & 20 & 8 & Plasma & $\begin{array}{l}3.07 \\
(1.90 \text { to } 4.23)\end{array}$ & $\begin{array}{l}7.59(5.37 \text { to } \\
9.81)\end{array}$ & NR & AAS \\
\hline $\begin{array}{l}\text { Alatise and } \\
\text { Schrauzer }\end{array}$ & Nigeria (2010) & 12 & 12 & Plasma & $\begin{array}{l}-0.44 \\
(-1.25 \text { to } 0.37)\end{array}$ & NR & $\begin{array}{l}0.38 \\
(-0.43 \text { to } 1.19)\end{array}$ & ICP-MS \\
\hline $\begin{array}{l}\text { Alatise and } \\
\text { Schrauzer }{ }^{35}\end{array}$ & Nigeria (2010) & 12 & 12 & Scalp hair & $\begin{array}{l}5.10 \\
(3.39 \text { to } 6.80)\end{array}$ & $\begin{array}{l}-0.32 \\
(1.13 \text { to } 0.48)\end{array}$ & $\begin{array}{l}-2.21 \\
(-3.24 \text { to }-1.18)\end{array}$ & ICP-MS \\
\hline $\begin{array}{l}\text { Romanowicz- } \\
\text { Makowska et al }{ }^{71}\end{array}$ & Poland (20II) & 67 & 16 & $\begin{array}{l}\text { Breast } \\
\text { tissue }\end{array}$ & $\begin{array}{l}0.42 \\
(-0.13 \text { to } 0.97)\end{array}$ & $\begin{array}{l}0.55 \\
(0.01 \text { to } 1.10)\end{array}$ & NR & FAAS \\
\hline Cihan et $\mathrm{al}^{36}$ & Turkey (20II) & 52 & 52 & Scalp hair & $\begin{array}{l}0.69 \\
(0.30 \text { to } 1.09)\end{array}$ & $\begin{array}{l}-0.19 \\
(0.58 \text { to } 0.19)\end{array}$ & $\begin{array}{l}0.9 \mathrm{I} \\
(0.50 \text { to } \mathrm{I} .3 \mathrm{I})\end{array}$ & ICP-MS \\
\hline $\begin{array}{l}\text { Blaurock-Busch } \\
\text { et } \mathrm{a}^{24}\end{array}$ & India (20I4) & 15 & 50 & Scalp hair & $\begin{array}{l}0.80 \\
(0.21 \text { to } 1.40)\end{array}$ & $N R$ & $\begin{array}{l}0.00 \\
(-0.58 \text { to } 0.58)\end{array}$ & ICP-MS \\
\hline Wadhwa et al ${ }^{19}$ & Pakistan (20I5) & 47 & 94 & Scalp hair & $\begin{array}{l}2.82 \\
(2.34 \text { to } 3.30)\end{array}$ & $\begin{array}{l}3.52 \\
(2.98 \text { to } 4.06)\end{array}$ & $\begin{array}{l}6.90 \\
(6.02 \text { to } 7.79)\end{array}$ & AAS \\
\hline Foster et $\mathrm{a}^{52}$ & Canada (2008) & 326 & 120 & Toenail & $\begin{array}{l}-0.07 \\
(-0.28 \text { to } 0.14)\end{array}$ & $\mathrm{NR}$ & $\begin{array}{l}-0.20 \\
(-0.4 I \text { to } 0.0 I)\end{array}$ & NAA \\
\hline Millos et $\mathrm{a}^{51}$ & Spain (2008) & 19 & 20 & $\begin{array}{l}\text { Breast } \\
\text { tissue }\end{array}$ & NR & $\begin{array}{l}1.70 \\
(0.96 \text { to } 2.44)\end{array}$ & $\begin{array}{l}1.20 \\
(0.51 \text { to } 1.88)\end{array}$ & ICP-AES \\
\hline Farah et $\mathrm{a}^{72}$ & USA (20I0) & 24 & 24 & $\begin{array}{l}\text { Breast } \\
\text { tissue }\end{array}$ & NR & $\begin{array}{l}1.60 \\
(0.95 \text { to } 2.25)\end{array}$ & $N R$ & ICP-AES \\
\hline Drake and Sky-Peck ${ }^{53}$ & USA (1989) & 26 & 26 & $\begin{array}{l}\text { Breast } \\
\text { tissue }\end{array}$ & NR & $\begin{array}{l}0.58 \\
(0.03 \text { to } 1.14)\end{array}$ & $\begin{array}{l}-0.54 \\
(-1.09 \text { to } 0.02)\end{array}$ & INAA \\
\hline Magalhaes et a $\mathrm{l}^{73}$ & $\begin{array}{l}\text { Portugal, } \\
\text { Germany } \\
(2008)\end{array}$ & 15 & 15 & $\begin{array}{l}\text { Breast } \\
\text { tissue }\end{array}$ & NR & $\begin{array}{l}1.00 \\
(0.24 \text { to } 1.76)\end{array}$ & NR & TXRF \\
\hline Rizk and Sky-Peck ${ }^{54}$ & USA (1984) & 25 & 25 & $\begin{array}{l}\text { Breast } \\
\text { tissue }\end{array}$ & NR & $\begin{array}{l}0.54 \\
(0.02 \text { to } I . I I)\end{array}$ & $\begin{array}{l}-0.54 \\
(-1.1 \text { to } 0.03)\end{array}$ & AAS \\
\hline Pasha et $\mathrm{a}^{74}$ & Pakistan (20I0) & 33 & 35 & Scalp hair & $\begin{array}{l}6.63 \\
(5.40 \text { to } 7.86)\end{array}$ & $\begin{array}{l}8.30 \\
(6.80 \text { to } 9.79)\end{array}$ & NR & AAS \\
\hline Pasha et $\mathrm{a}^{74}$ & Pakistan (20I0) & 36 & 35 & Scalp hair & $\begin{array}{l}\text { II.38 } \\
\text { (9.42 to } 13.33)\end{array}$ & $\begin{array}{l}5.23 \\
(4.24 \text { to } 6.22)\end{array}$ & NR & AAS \\
\hline Garg et $\mathrm{al}^{55}$ & India (1994) & 30 & 30 & $\begin{array}{l}\text { Breast } \\
\text { tissue }\end{array}$ & NR & $\mathrm{NR}$ & $\begin{array}{l}0.09 \\
(-0.42 \text { to } 0.60)\end{array}$ & INAA \\
\hline Garland et $\mathrm{al}^{56}$ & USA (1996) & 433 & 433 & Toenail & NR & NR & $\begin{array}{l}0.00 \\
(-0.13 \text { to } 0.13)\end{array}$ & NR \\
\hline
\end{tabular}

Abbreviations: AAS, atomic absorption spectrophotometry; FAAS, flame atomic absorption spectrometry; ICP-AES, inductively coupled plasma-atomic emission spectrometry; ICP-MS, inductively coupled plasma mass spectrometry; INAA, instrumental neutron activation analysis; NR, not reported; TXRF, X-ray fluorescence spectrometry.

Table 2 The overall results obtained from the analysis of the trials included in this study

\begin{tabular}{llll}
\hline Standard mean difference; $P$-value & & \\
\hline Matrix & Cadmium & Nickel & Arsenic \\
\hline Plasma & $1.29 ; P=0.463$ & $7.59 ; P=0.00$ & $0.38 ; P=0.358$ \\
Breast tissues & $-0.00 ; P=0.999$ & $0.96 ; P=0.00$ & $0.03 ; P=0.928$ \\
Scalp hair and toenail & $3.64 ; P=0.00$ & $3.25 ; P=0.014$ & $0.87 ; P=0.084$ \\
\hline
\end{tabular}

studies showed no significant associations (Figure 2). As is seen in Table 1, Cd status based on analysis of plasma, breast tissues, and scalp hair was reported in 2, 2, and 6 studies, respectively. The present meta-analysis showed a statistically significant difference in Cd statuses between healthy controls and BC patients only in one subgroup (scalp hair and toenail), the SMD of which was 3.64 (95\% CI: $2.08-5.21 ; P=0.00)$, 


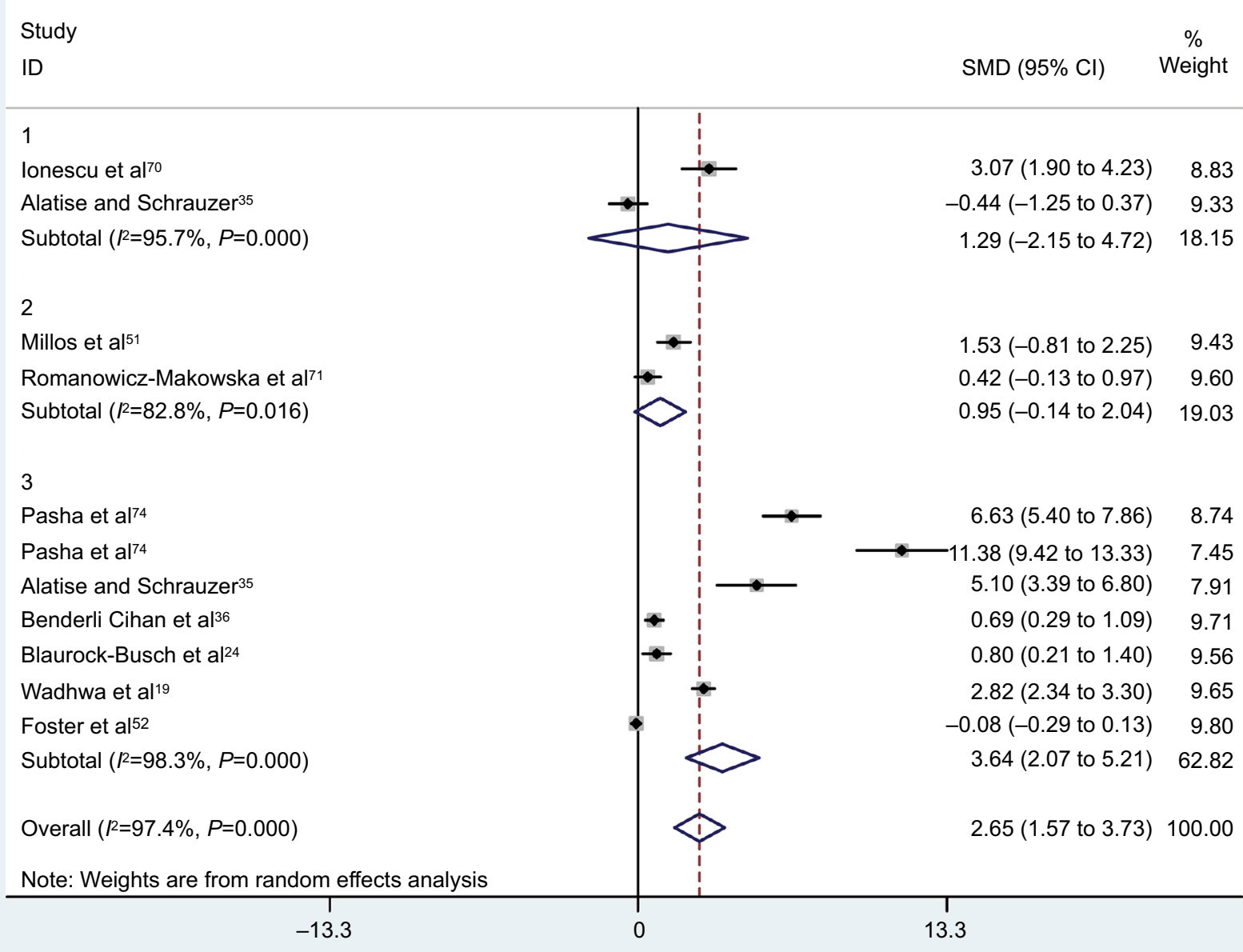

Figure 2 Meta-analysis of the association of Cd concentration with breast cancer risk: 1) plasma, 2) breast tissue and 3) scalp hair and toenail.

Notes: Square represents effect estimate of individual studies with their $95 \%$ Cls with size of squares proportional to the weight assigned to the study in the meta-analysis. In this chart, studies are presented in the order of the year of publication and author's names, based on a random effects model.

Abbreviation: SMD, standard mean difference.

whereas no statistically significant difference was found in Cd statuses between healthy controls and BC patients related to plasma and breast tissues subgroups; their SMD was 1.29 (95\% CI: -2.15 to $4.72 ; P=0.463$ ) and -0.00 (95\% CI: -0.79 to $0.79 ; P=0.999)$, respectively.

However, the overall integration of data from 11 studies into our meta-analysis demonstrated that $\mathrm{Cd}$ status was associated with increased $\mathrm{BC}$ risk using a random-effects model with the SMD being 2.45 (95\% CI: $1.40-3.50 ; P=0.000)$ (Figure 2).

Figure 3 shows the findings of the meta-analysis conducted on the relationship between $\mathrm{Ni}$ concentrations and $\mathrm{BC}$ in various subgroups. As can be observed, in 1 study, $\mathrm{Ni}$ status was based on the analysis of "plasma" and in 6 studies, "breast tissues" were the sample specimens used, whereas in the other 5 studies, "scalp hair" was the sample specimen. The results of our meta-analysis were indicative of a statistically significant difference in all subgroups. The SMD were as follows: 1: plasma 7.59 (95\% CI: 5.37-9.81; $P=0.00$ ), 2: breast tissue 0.84 (95\% CI: $0.51-1.17 ; P=0.00$ ), 3: scalp hair 3.25 (95\% CI: $0.67-5.83 ; P=0.014)$. The overall integration of data from the 3 groups led to the conclusion that differences were found in Ni status between healthy and $\mathrm{BC}$ patients, with the mean difference being 2.33 (95\% CI: $1.26-3.39 ; P=0.000)$.

In the present meta-analysis, 11 studies reported the relationship between As concentrations and $\mathrm{BC}$ in various subgroups; 1 study was based on the analysis of plasma, 4 studies were based on the analysis of breast tissues, 5 studies were based on the analysis of scalp hair, and 2 studies based on the analysis of toenail (Table 1). Our findings indicated no statistically significant difference in all subgroups; As statuses between healthy controls and BC patients showed the SMD for plasma was $0.38(95 \%$ 


\section{Study}

ID

$$
\text { SMD }(95 \% \mathrm{Cl}) \quad \begin{gathered}
\% \\
\text { Weight }
\end{gathered}
$$

$$
1
$$

Lonescu et al 70

Subtotal $(2=0 \%)$

2

Rizk and Sky-Peck ${ }^{54}$

Drake and Sky-Peck ${ }^{53}$

Magalhaes et al ${ }^{73}$

Millos et al ${ }^{51}$

Farah et al72

Romanowicz-Makowska et al ${ }^{71}$

Subtotal $(/ 2=41.5 \%, P=0.129)$

3

Pasha et $\mathrm{al}^{74}$

Pasha et al ${ }^{74}$

Alatise and Schrauzer ${ }^{35}$

Benderli Cihan et al ${ }^{36}$

Wadhwa et al ${ }^{19}$

Subtotal $(/ 2=98.6 \%, P=0.000)$

Overall $(2=96.7 \%, P=0.000)$

Note: Weights are from random effects analysis

Figure 3 Meta-analysis of the association of $\mathrm{Ni}$ concentration with breast cancer risk: I) plasma, 2) breast tissue, 3) scalp hair and toenail.

Notes: Square represents effect estimate of individual studies with their $95 \%$ Cls with size of squares proportional to the weight assigned to the study in the meta-analysis. In this chart, studies are presented in the order of the year of publication and author's names, based on a random effects model.

Abbreviation: SMD, standard mean difference.

CI: -0.43 to $1.19 ; P=0.358), 0.03(95 \% \mathrm{CI}:-0.68$ to 0.75 ; $P=0.928$ for breast tissues), and 0.87 (95\% CI: -0.12 to $1.85 ; P=0.084$ for scalp hair and toenail) (Figure 4). Also, among 11 studies reporting the association between As concentrations and $\mathrm{BC}$, only 3 showed a significant link between As concentrations and BC. As seen in Figure 4, by using a random-effects model, the overall integration of data from these studies showed no association between As status with the risk of $\mathrm{BC}$; the SMD of which was 0.52 (95\% CI: -0.12 to $1.16 ; P=0.114$ ).

\section{Publication bias}

Publication bias was checked using Begg's funnel plot. To check publication bias, the studies were sorted from the most precise to the least precise (according to standard error) and then we ran a cumulative random-effect meta-analysis.
There was no significant publication bias $(P=0.484)$; this meant that both tests ( 1 with positive and the other with negative results) have been published (Figure 4).

\section{Discussion}

Heavy metals are formed as a result of industrial processing. As these contaminate the environment, this is a growing concern for bioaccumulation of heavy metals in the body. ${ }^{29}$ Complexes with different organic compounds are formed in these heavy metals, which disrupt the physiological functions of the body with their toxic effects. ${ }^{30}$

The toxic effects of heavy metals include: DNA damage, impaired mitochondrial function, oxidative stress, deregulated cell growth, and cell death. ${ }^{31}$

In the present meta-analysis, we examined the relationship between BC and Cd levels. Combining the results from 


\section{Study}

ID

\section{SMD $(95 \% \mathrm{Cl}) \quad$ Weight}

1

Alatise and Schrauzer ${ }^{35}$

Subtotal $(/ 2=0 \%)$

2

Rizk and Sky-Peck ${ }^{54}$

Drake and Sky-Peck53

Garg et al ${ }^{55}$

Millos et al 51

Subtotal $(I=84.1 \%, P=0.000)$

3

Garland et al56

Alatise and Schrauzer ${ }^{35}$

Benderli Cihan et al ${ }^{36}$

Blaurock-Busch et al ${ }^{24}$

Wadhwa et al ${ }^{19}$

Foster et al ${ }^{52}$

Subtotal $\left(I^{2}=98.2 \%, P=0.000\right)$

Overall $(R=96.6 \%, P=0.000)$

Note: Weights are from random effects analysis

$$
-7.79
$$

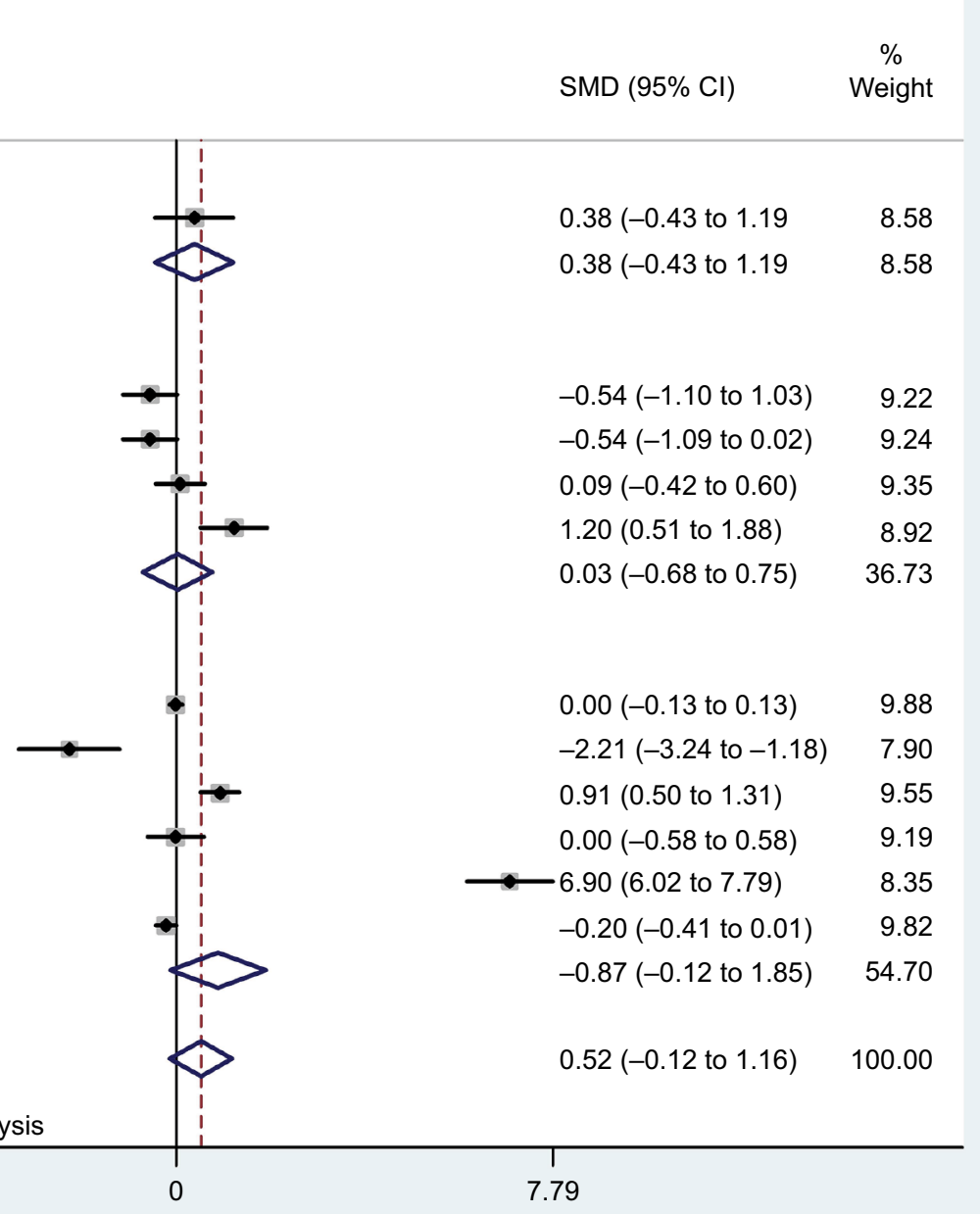

Figure 4 Meta-analysis of the association of I: plasma, 2: breast tissues 3: scalp hair and toenail Arsenic concentration with breast cancer risk.

Notes: Square represents effect estimate of individual studies with their $95 \% \mathrm{Cls}$ with size of squares proportional to the weight assigned to the study in the meta-analysis. In this chart, studies are presented in order of the year of publication and author's names, based on a random effects model.

Abbreviation: SMD, standard mean difference.

11 epidemiologic studies (Figure 2) indicates that high levels of $\mathrm{Cd}$ were positively associated with the risk of subsequent $\mathrm{BC}(P=0.000)$. Recent clinical studies have revealed that high concentrations of $\mathrm{Cd}$ are found in $\mathrm{BC}$ patients; ${ }^{32}$ these levels are significantly higher than those in normal controls. ${ }^{33}$ Also, in some studies, a marginally significant association was observed between $\mathrm{BC}$ risk and $\mathrm{Cd}$ levels. ${ }^{19,24,34-36} \mathrm{~A}$ case-control sample of women living in Long Island also found a similar association. ${ }^{37}$ Similar to these studies, the Long Island study estimated that about $35 \%$ of BC occurring in the USA may be attributed to exposure to $\mathrm{Cd}$. Since the case-control studies were conducted in BC patients, it is not clear whether $\mathrm{Cd}$ is linked to the risk of developing $\mathrm{BC}$. In a recent prospective cohort study on postmenopausal women, it was reported that the risk of $\mathrm{BC}$ increases with long-term dietary intake of $\mathrm{Cd} .^{38}$ Although these studies suggest a correlation between $\mathrm{Cd}$ exposure and the incidence of $\mathrm{BC}$, they fail to determine whether $\mathrm{Cd}$ plays a role in the etiology of $\mathrm{BC}$ or not.

In the present study, the relationship between Ni levels and $\mathrm{BC}$ was examined. Combining the results from 12 epidemiologic studies (Figure 3) indicates that high levels of Ni were positively related to the risk of subsequent BC. Essential metals such as Ni have a key role in membrane integrity and permeability, metabolism and respiration, cell proliferation, and death. ${ }^{39,40}$ But diseases or toxicity may occur in the wake of variations in their concentrations..$^{40-42}$ For example, low concentrations of essential metals have a key role in enzyme activity but high concentrations disrupt enzyme activity. ${ }^{41}$

International Agency for Research on Cancer has classified certain $\mathrm{Ni}, \mathrm{Cd}$, and even As compounds as carcinogenic since the late $1970 \mathrm{~s}$ and $1980 \mathrm{~s} .{ }^{32,43,44}$ Our results demonstrated 
that high levels of $\mathrm{Ni}$ and $\mathrm{Cd}$ were positively related to the risk of $\mathrm{BC}$. These findings are similar to a review conducted by Aquino et al in which the relationship between $\mathrm{Cd}, \mathrm{Ni}$, and cancer was examined. They found that most studies analyzed how exposure to heavy metals influences the progression and development of $\mathrm{BC} .{ }^{45}$ Aquino et $\mathrm{al}^{45}$ concluded that continuous exposure to $\mathrm{Ni}$ and $\mathrm{Cd}$ at concentrations well below standard WHO limits is still dangerous due to the bioaccumulation phenomenon and especially high affinity for specific organic proteins like estrogen receptors (ERs).

Recent studies have revealed that $\mathrm{Ni}$ and $\mathrm{Cd}$ can imitate the activities of estrogens and disrupt endocrine functions of the body. As a result, metalloestrogens is the result of this process. ${ }^{31,46,47}$ Byrne et $\mathrm{al}^{48}$ in a review study demonstrated that metalloestrogens such as $\mathrm{Cd}$ and $\mathrm{Ni}$ include bivalent cations and metal/metalloid anions. In the absence of estradiol, metalloestrogens activate ERs. Therefore, exposure to these metals can increase $\mathrm{BC}$ risk. However, since estrogen has a key role in the progression of $\mathrm{BC}$, metalloestrogens may contribute to the progression and development of $\mathrm{BC}$ by activating the ERs. ${ }^{47,49}$ In recent years, environmental exposure to the metalloestrogens has increased significantly and become quite widespread. One of the specific characteristics of most metalloestrogens is having a long biological halflife (e.g., Cd has a half-life of 10-30 years) and hence their accumulation in the body, especially in breasts. ${ }^{48}$ Evidence has shown that $\mathrm{Cd}$ may play a role in $\mathrm{BC}$ by activating $\mathrm{ER} \alpha$ in vivo and in vitro. ${ }^{48}$ It is hypothesized that an important step in the carcinogenic process is the activation of ERs through metal-induced processes. ${ }^{50} \mathrm{In}$ addition, $\mathrm{Cd}$ has been shown to induce various pro-survival and cell cycle regulatory genes. These results suggest that even low dose and acute exposure to $\mathrm{Cd}$ can cause DNA damage in normal BC cells. ${ }^{46}$

However, although there is evidence linking exposure to this metal with $\mathrm{BC}$, the etiological role of metalloestrogens $(\mathrm{Cd}, \mathrm{Ni}$, etc. $)$ as underlying agents of the disease is yet to be established by more solid evidence.

In the present meta-analysis, the relationship between As levels and $\mathrm{BC}$ was examined. Combining the results from 11 epidemiologic studies (Figure 4) reveals that there are no associations between the levels of As and BC risk $(P=0.114)$. Some studies indicate that the levels of As are higher in samples of cancer patients when compared with healthy controls, ${ }^{19,36,51}$ whereas, no statistically significant difference was found among As statuses, controls, and BC in most selected studies in this meta-analysis. ${ }^{24,35,52-56}$ Even sketchier is the evidence linking As to BC. Although, Hinwood et al in their case study in Australia reported that $40 \%$ of the BCs were caused by As-contaminated drinking water; ${ }^{57,58}$ in vitro and in vivo studies indicate that As disrupts the function of ER and actually suppresses the signaling pathway of estrogen. ${ }^{59,60}$ Research findings from a review conducted by Aquino et al demonstrate that As is a potential metalloestrogen. ${ }^{45}$ With regard to As-induced cancer, several modes of action have been proposed for carcinogenicity of As, including inducing genetic damage, inhibiting DNA repair, altering DNA methylation patterns, inducing cell death and proliferation, and acting as a cocarcinogen. ${ }^{61}$ Moreover, the association between different types of cancer and As exposure has been reported.$^{62}$ There is some evidence of carcinogenic effects of As-contaminated drinking causing various cancers. ${ }^{19}$ Nonetheless, a large body of evidence indicates that As compounds induce cell death in $\mathrm{BC}$ cells and therefore use of these toxic compounds can be justified in the treatment of BC.

For example, the effects of estradiol are copied by sodium arsenite and this process leads to the proliferation of cells in the estrogen-responsive BC cell line MCF-7, while the S-phase recruitment is increased..$^{63}$ Interestingly, with regard to the proliferation of cells, a paradoxical effect was observed. Cell proliferation was induced by lower concentrations $(<5 \mu \mathrm{M})$ of sodium arsenite while apoptosis was caused by longer treatment periods or higher concentrations $(>5 \mu \mathrm{M}) .{ }^{64}$ In addition, As influences the contribution of enzymes in the folate cycle. ${ }^{64}$ Liu et $\mathrm{al}^{65}$ and Wang et $\mathrm{al}^{66}$ showed that the proliferation of cells significantly increased after 24-hour exposure to $\mathrm{As}_{2} \mathrm{O}_{3}(0.01-1 \mu \mathrm{M})$ and a progression from the $\mathrm{G} 1$ to $\mathrm{S} / \mathrm{G} 2$ phases occurred in the non-tumorigenic MCF10A breast epithelial cell line. Some effects are possibly due to the reduced clearance of plasma, an enhanced tumor uptake, and an induction apoptosis process of tumor cells. ${ }^{67}$

Exposure of humans to these metals is primarily through dietary sources of water and food, air, cigarettes, and occupational exposure, which leads to their significant accumulation in the body. ${ }^{48}$

\section{Limitations}

The limitations of the current study were largely related to the methodology used for the reviewed studies. One of the limitations in our study was the fact that no age group was analyzed. A recent study published by Julin et al ${ }^{38}$ demonstrates a correlation between $\mathrm{BC}$ risk and dietary $\mathrm{Cd}$ exposure in postmenopausal women. It is not quite clear whether human exposure to $\mathrm{Ni}$ or $\mathrm{Cd}$ increases the risk of BC. Therefore, more comprehensive analyses should be conducted in the future. 
Other limitations are as follows:

1. All methods of variance measurement were not uniform.

2. Not enough information was available about the lifestyle and nutrition of the participants.

3. Different kinds of screening methods and not a uniform standard unit for measuring toxic elements' concentrations in different articles were found.

\section{Conclusion}

A large body of evidence confirms serious concerns over the growing use of environmental contaminants such as $\mathrm{Cd}$ and $\mathrm{Ni}$, as the health of thousands of people can be jeopardized even by minimal levels of $\mathrm{Ni}$ and $\mathrm{Cd}$. In conclusion, this meta-analysis, based on random-effects model, confirms a direct and positive association between the risk of $\mathrm{BC}$ and $\mathrm{Ni}$ and $\mathrm{Cd}$ concentrations. Overall, contaminants like these metals are among possible risk factors for causing cancer due to their widespread proliferation in water and food sources, and vast application in various industries.

Therefore, $\mathrm{Cd}$ and $\mathrm{Ni}$ concentrations must be meticulously controlled in sources of water, food, medicine, etc. In summary, the results of this study can be used in clinical trials for the prevention of $\mathrm{BC}$ by controlling $\mathrm{Ni}$ and $\mathrm{Cd}$ levels in diet.

\section{Acknowledgment}

We would like to acknowledge the Students Researches Committee of the Goletsan University of Medical Sciences.

\section{Author contributions}

All authors contributed toward data analysis, drafting and revising the paper and agree to be accountable for all aspects of the work.

\section{Disclosure}

The authors report no conflicts of interest in this work.

\section{References}

1. Ghoncheh M, Pournamdar Z, Salehiniya H. Incidence and mortality and epidemiology of breast cancer in the world. Asian Pac J Cancer Prev. 2016;17(17(S3):43-46.

2. Torre LA, Bray F, Siegel RL, Ferlay J, Lortet-Tieulent J, Jemal A. Global cancer statistics, 2012. CA Cancer J Clin. 2015;65(2):87-108.

3. Jemal A, Bray F, Center MM, Ferlay J, Ward E, Forman D. Global cancer statistics. CA Cancer J Clin. 2011;61(2):69-90.

4. Benson JR, Jatoi I. The global breast cancer burden. Future Oncol. 2012;8(6):697-702.

5. Youlden DR, Cramb SM, Yip CH, Baade PD. Incidence and mortality of female breast cancer in the Asia-Pacific region. Cancer Biol Med. 2014;11(2):101-115.
6. Yang C, He Y, Zhang H, et al. Selective killing of breast cancer cells expressing activated CD44 using CD44 ligand-coated nanoparticles in vitro and in vivo. Oncotarget. 2015;6(17):15283-15296.

7. Fritsche H, Heilmann T, Tower RJ, et al. TRAIL-R2 promotes skeletal metastasis in a breast cancer xenograft mouse model. Oncotarget. 2015;6(11):9502-9516.

8. Manso L, Moreno F, Márquez R, et al. Use of bevacizumab as a first-line treatment for metastatic breast cancer. Curr Oncol. 2015;22(2):e51-e60.

9. Xiao G, Wang X, Wang J, et al. CXCL16/CXCR6 chemokine signaling mediates breast cancer progression by pERK1/2-dependent mechanisms. Oncotarget. 2015;6(16):14165-14178.

10. Wood RY, Della-Monica NR. Psychosocial factors influencing breast cancer risk appraisal among older women. Qual Health Res. 2011;21(6):783-795.

11. Salhab M, Bismohun S, Mokbel K. Risk-reducing strategies for women carrying BRCA1/2 mutations with a focus on prophylactic surgery. BMC Women's Health. 2010;10(1):28.

12. Jevtic M, Velicki R, Popovic M, Cemerlic-Adjic N, Babovic S, Velicki L. Dietary influence on breast cancer. J BUON. 2010;15(3):455-461.

13. Ebrahim AM, Eltayeb M, Shaat M, Mohmed NM, Eltayeb E, Ahmed AY. Study of selected trace elements in cancerous and non-cancerous human breast tissues from Sudanese subjects using instrumental neutron activation analysis. Sci Total Environ. 2007;383(1):52-58.

14. Florea A-M, Büsselberg D. Metals and breast cancer: risk factors or healing agents? J Toxicol. 2011;2011:159619.

15. Ilychova SA, Zaridze DG. Cancer mortality among female and male workers occupationally exposed to inorganic lead in the printing industry. Occup Environ Med. 2012;69(2):87-92.

16. Qu W, Tokar EJ, Kim AJ, Bell MW, Waalkes MP. Chronic cadmium exposure in vitro causes acquisition of multiple tumor cell characteristics in human pancreatic epithelial cells. Environ Health Perspect. 2012;120(9):1265-1271.

17. Cheung MR. Blood lead concentration correlates with all cause, all cancer and lung cancer mortality in adults: a population based study. Asian Pac J Cancer Prev. 2013;14(5):3105-3108.

18. Person RJ, Tokar EJ, Xu Y, Orihuela R, Ngalame NN, Waalkes MP. Chronic cadmium exposure in vitro induces cancer cell characteristics in human lung cells. Toxicol Appl Pharmacol. 2013;273(2):281-288.

19. Wadhwa SK, Kazi TG, Afridi HI, Talpur FN. Interaction between carcinogenic and anti-carcinogenic trace elements in the scalp hair samples of different types of Pakistani female cancer patients. Clin Chim Acta. 2015;439:178-184.

20. Waalkes MP, Ward JM, Liu J, Diwan BA. Transplacental carcinogenicity of inorganic arsenic in the drinking water: induction of hepatic, ovarian, pulmonary, and adrenal tumors in mice. Toxicol Appl Pharmacol. 2003;186(1):7-17.

21. Huff J, Chan P, Nyska A. Is the human carcinogen arsenic carcinogenic to laboratory animals? Toxicol Sci. 2000;55(1):17-23.

22. Hossain K, Akhand AA, Kato M, et al. Arsenite induces apoptosis of murine $\mathrm{T}$ lymphocytes through membrane raft-linked signaling for activation of c-Jun amino-terminal kinase. J Immunol. 2000; 165(8):4290-4297.

23. Chen $\mathrm{Y}$, Ahsan H. Cancer burden from arsenic in drinking water in Bangladesh. Am J Public Health. 2004;94(5):741-744.

24. Blaurock-Busch E, Busch YM, Friedle A, Buerner H, Parkash C, Kaur A. Comparing the metal concentration in the hair of cancer patients and healthy people living in the Malwa region of Punjab, India. Clin Med Insights Oncol. 2014;8:1-13.

25. Andersen A, Berge S, Engeland A, Norseth T. Exposure to nickel compounds and smoking in relation to incidence of lung and nasal cancer among nickel refinery workers. Occup Environ Med. 1996;53(10): $708-713$.

26. Costa M. Mechanisms of nickel genotoxicity and carcinogenicity. Toxicology of metals CRC Press, Boca Raton, FL; 1996:245-251.

27. Hartwig A, Mullenders LH, Schlepegrell R, Kasten U, Beyersmann D. Nickel (II) interferes with the incision step in nucleotide excision repair in mammalian cells. Cancer Res. 1994;54(15):4045-4051. 
28. Lee Y, Klein C, Kargacin B, et al. Carcinogenic nickel silences gene expression by chromatin condensation and DNA methylation: a new model for epigenetic carcinogens. Mol Cell Biol. 1995;15(5):2547-2557.

29. Islam Eu, Yang XE, He ZL, Mahmood Q. Assessing potential dietary toxicity of heavy metals in selected vegetables and food crops. $J$ Zhejiang Univ Sci B. 2007;8(1):1-13.

30. Nikolic J, Sokolovic D. Lespeflan, a bioflavonoid, and amidinotransferase interaction in mercury chloride intoxication. Ren Fail. 2004;26(6):607-611.

31. Misra UK, Gawdi G, Akabani G, Pizzo SV. Cadmium-induced DNA synthesis and cell proliferation in macrophages: the role of intracellular calcium and signal transduction mechanisms. Cell Signal. 2002;14(4):327-340.

32. Cancer IAfRo. Cadmium and Cadmium Compounds. IARC Monogr Eval Caracinog Risk Hum 100C; 1976:39-74.

33. Cancer IAfRo. Cadmium and Cadmium Compounds. IARC Monogr Eval Caracinog Risk Hum 100C; 1993:119-237.

34. McElroy JA, Shafer MM, Trentham-Dietz A, Hampton JM, Newcomb PA. Cadmium exposure and breast cancer risk. J Natl Cancer Inst. 2006;98(12):869-873.

35. Alatise OI, Schrauzer GN. Lead exposure: a contributing cause of the current breast cancer epidemic in Nigerian women. Biol Trace Elem Res. 2010;136(2):127-139.

36. Cihan YB, Sözen S, Yıldırım SÖ. Trace elements and heavy metals in hair of stage III breast cancer patients. Biol Trace Elem Res. 2011;144(1-3):360-379.

37. Gallagher CM, Chen JJ, Kovach JS. Environmental cadmium and breast cancer risk. Aging (Albany NY). 2010;2(11):804-814.

38. Julin B, Wolk A, Bergkvist L, Bottai M, Åkesson A. Dietary cadmium exposure and risk of postmenopausal breast cancer: a population-based prospective cohort study. Cancer Res. 2012;72(6):1459-1466.

39. Krizek M, Senft V, Motan J. [Copper and the human body]. Cas Lek Cesk. 1997;136(22):698-701. Czech.

40. Chan S, Gerson B, Subramaniam S. The role of copper, molybdenum, selenium, and zinc in nutrition and health. Clin Lab Med. 1998;18(4):673-685.

41. Cantley LC Jr, Aisen P. The fate of cytoplasmic vanadium. Implications on (NA, K)-ATPase inhibition. J Biol Chem. 1979;254(6):1781-1784.

42. Chan PC, Peller OG, Kesner L. Copper (II)-catalyzed lipid peroxidation in liposomes and erythrocyte membranes. Lipids. 1982;17(5):331-337.

43. Cancer IAfRo. Nickel and nickel compounds. IARC Monogr Eval Carcinog Risk Chem Man; 1976:75-112.

44. Cancer IAfRo. Arsenic and arsenic compounds. IARC Monogr Eval Carcinog Risk Chem Hum; 1980:39-141.

45. Aquino NB, Sevigny MB, Sabangan J, Louie MC. The role of cadmium and nickel in estrogen receptor signaling and breast cancer: metalloestrogens or not? J Environ Sci Health C Environ Carcinog Ecotoxicol Rev. 2012;30(3):189-224.

46. Luevano J, Damodaran C. A review of molecular events of cadmiuminduced carcinogenesis. J Environ Pathol Toxicol Oncol. 2014;33(3): 183-194.

47. Martin MB, Reiter R, Pham T, et al. Estrogen-like activity of metals in MCF-7 breast cancer cells. Endocrinology. 2003;144(6):2425-2436.

48. Byrne C, Divekar SD, Storchan GB, Parodi DA, Martin MB. Metals and breast cancer. J Mammary Gland Biol Neoplasia. 2013;18(1):63-73.

49. Darbre P. Metalloestrogens: an emerging class of inorganic xenoestrogens with potential to add to the oestrogenic burden of the human breast. J Appl Toxicol. 2006;26(3):191-197.

50. Stoica A, Katzenellenbogen BS, Martin MB. Activation of estrogen receptor- $\alpha$ by the heavy metal cadmium. Mol Endocrinol. 2000;14(4): $545-553$.

51. Millos J, Costas-Rodriguez M, Lavilla I, Bendicho C. Multielemental determination in breast cancerous and non-cancerous biopsies by inductively coupled plasma-mass spectrometry following small volume microwave-assisted digestion. Anal Chim Acta. 2008;622(1):77-84.
52. Foster HD, Kennedy G, Maisonneuve K, Krewski D, Ghadirian P. A case-control study of toenail selenium, mercury, arsenic and cadmium and cancer of the breast, colon and prostate in Montreal. Trends Cancer Res. 2008;4:15-18.

53. Drake EN, Sky-Peck HH. Discriminant analysis of trace element distribution in normal and malignant human tissues. Cancer Res. 1989;49(15):4210-4215.

54. Rizk SL, Sky-Peck HH. Comparison between concentrations of trace elements in normal and neoplastic human breast tissue. Cancer Res. 1984;44(11):5390-5394.

55. Garg A, Singh V, Weginwar R, Sagdeo V. An elemental correlation study in cancerous and normal breast tissue with successive clinical stages by neutron activation analysis. Biol Trace Elem Res. 1994;46(3): 185-202.

56. Garland M, Morris JS, Colditz GA, et al. Toenail trace element levels and breast cancer: a prospective study. Am J Epidemiol. 1996; 144(7):653-660.

57. Hinwood A, Sim M, Jolley D, et al. Risk factors for increased urinary inorganic arsenic concentrations from low arsenic concentrations in drinking water. Int J Environ Health Res. 2003;13(3):271-284.

58. Hinwood AL, Sim MR, Jolley D, et al. Hair and toenail arsenic concentrations of residents living in areas with high environmental arsenic concentrations. Environ Health Perspect. 2003;111(2):187-193.

59. Chatterjee A, Chatterji U. Arsenic abrogates the estrogen-signaling pathway in the rat uterus. Reprod Biol Endocrinol. 2010;8(1):80.

60. Davey JC, Bodwell JE, Gosse JA, Hamilton JW. Arsenic as an endocrine disruptor: effects of arsenic on estrogen receptor-mediated gene expression in vivo and in cell culture. Toxicol Sci. 2007;98(1):75-86.

61. Liu J, Chen H, Miller DS, et al. Overexpression of glutathione $\mathrm{S}$-transferase II and multidrug resistance transport proteins is associated with acquired tolerance to inorganic arsenic. Mol Pharmacol. 2001;60(2):302-309.

62. Wadhwa SK, Kazi TG, Kolachi NF, et al. Case-control study of male cancer patients exposed to arsenic-contaminated drinking water and tobacco smoke with relation to non-exposed cancer patients. Hum Exp Toxicol. 2011;30(12):2013-2022.

63. Ruiz-Ramos R, López-Carrillo L, Albores A, Hernández-Ramírez RU, Cebrian ME. Sodium arsenite alters cell cycle and MTHFR, MT1/2, and c-Myc protein levels in MCF-7 cells. Toxicol Appl Pharmacol. 2009;241(3):269-274.

64. Ruiz-Ramos R, Lopez-Carrillo L, Rios-Perez AD, De Vizcaya-Ruíz A, Cebrian ME. Sodium arsenite induces ROS generation, DNA oxidative damage, HO-1 and c-Myc proteins, NF- $\mathrm{KB}$ activation and cell proliferation in human breast cancer MCF-7 cells. Mutat Res. 2009;674(1):109-115.

65. Liu Y, Hock JM, Sullivan C, et al. Activation of the p38 MAPK/Akt/ ERK1/2 signal pathways is required for the protein stabilization of CDC6 and cyclin D1 in low-dose arsenite-induced cell proliferation. $J$ Cell Biochem. 2010;111(6):1546-1555.

66. Wang X, Gao P, Long M, et al. Essential role of cell cycle regulatory genes $\mathrm{p} 21$ and $\mathrm{p} 27$ expression in inhibition of breast cancer cells by arsenic trioxide. Med Oncol. 2011;28(4):1225-1254.

67. Ahn RW, Chen F, Chen H, et al. A novel nanoparticulate formulation of arsenic trioxide with enhanced therapeutic efficacy in a murine model of breast cancer. Clin Cancer Res. 2010;16(14):3607-3617.

68. Liberati A, Altman DG, Tetzlaff J, et al. The PRISMA statement for reporting systematic reviews and meta-analyses of studies that evaluate health care interventions: explanation and elaboration. $B M J$. 2009;339:b2700.

69. Antila E, Mussalo-Rauhamaa H, Kantola M, Atroshi F, Westermarck T. Association of cadmium with human breast cancer. Sci Total Environ. 1996;186(3):251-256.

70. Ionescu JG, Novotny J, Stejskal V, Lätsch A, Blaurock-Busch E, Eisenmann-Klein M. Increased levels of transition metals in breast cancer tissue. Neuro Endocrinol Lett. 2006;27:36-39. 
71. Romanowicz-Makowska H, Forma E, Bryś M, Krajewska WM, Smolarz B. Concentration of cadmium, nickel and aluminum in female breast cancer. Pol J Pathol. 2011;62(4):257-261.

72. Farah IO, Trimble Q, Ndebele K, Mawson A. Significance of differential metal loads in normal versus cancerous cadaver tissues- biomed 2010 Biomed Sci Instrum. 2010;46:404-409.
73. Magalhaes T, Becker M, Carvalho M, Von Bohlen A. Study of Br, Zn, $\mathrm{Cu}$ and $\mathrm{Fe}$ concentrations in healthy and cancer breast tissues by TXRF. Spectrochim Acta Part B At Spectrosc. 2008;63(12):1473-1479.

74. Pasha Q, Malik SA, Shaheen N, Shah MH. Comparison of trace elements in the scalp hair of malignant and benign breast lesions versus healthy women. Biol Trace Element Res. 2010;134(2):160-173.
Cancer Management and Research

\section{Publish your work in this journal}

Cancer Management and Research is an international, peer-reviewed open access journal focusing on cancer research and the optimal use of preventative and integrated treatment interventions to achieve improved outcomes, enhanced survival and quality of life for the cancer patient The manuscript management system is completely online and includes

\section{Dovepress}

a very quick and fair peer-review system, which is all easy to use. Visit http://www.dovepress.com/testimonials.php to read real quotes from published authors. 